\title{
Structural study of uterine tubes of the rabbit (Oryctolagus cuniculus) at different postnatal periods
}

\author{
F.J. Al-Saffar ${ }^{1}$ and M.S. Almayahi ${ }^{2}$ \\ Department of Anatomy, College of Veterinary Medicine, University of Baghdad, Baghdad, Iraq \\ Email: ${ }^{1}$ assaffar1955@yahoo.com, ${ }^{2}$ masaratswadi44@gmail.com
}

(Received August 18, 2018; Accepted January 7, 2019)

\begin{abstract}
This study was designed to investigate the histomorphological changes in the uterine tubes of the local rabbits during three different periods of ages that were kitten, immature and mature stages of life. For such study, twenty-four female rabbits were used. Procedure of routine histological technique was performed to prepare histological sections by using general and special histochemical stains. Gross findings revealed the presence of bilateral uterine tubes which comprised thick short coiled preampulla, thin long ampulla and the isthmus which was shortest and straight region joined to the uterus. Microscopically three regions were identified according to the differences in their histological characteristic features. Data revealed that the wall of uterine tubes in kittens was not fully developed, whereas in immature does, global histological and histochemical changes were identified compared to kittens while mature does indicated critical role of the post weaning period on the development of the animals. Changes were specially recognized by histochemical procedure which showed strong positive reactions especially isthmus which obviously reacted with PAS, Ab, combined PAS-AB. In conclusion, current data showed unique differences of the uterine tubes in the local rabbits compared to other mammals especially those of rodentia species.
\end{abstract}

Keywords: Uterine tube, Does, Rabbits, Histochemistry

Available online at http://www.vetmedmosul.com

$$
\begin{aligned}
& \text { دراسة تركيبية للأنابيب الرحمية للأرنبة في فترات مختلفة بعد الولادة } \\
& \text { فايق جبار الصفار و مسرات سوادي المياحي } \\
& \text { فرع التشريح والأنسجة والأجنة، كلية الطب البيطري، جامعة بغداد، بغداد، العر اق }
\end{aligned}
$$

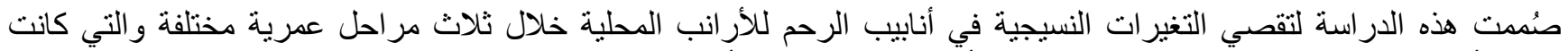

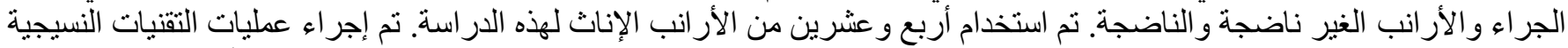

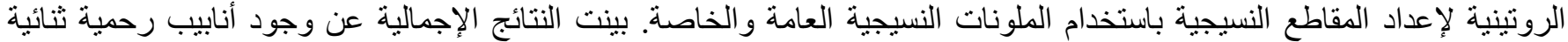

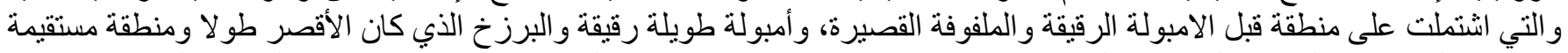

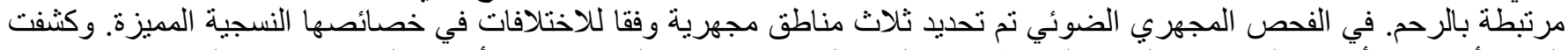

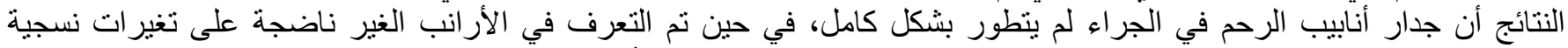

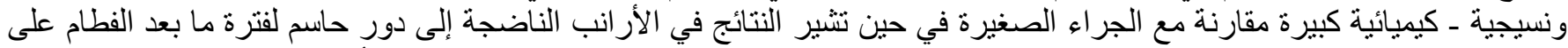

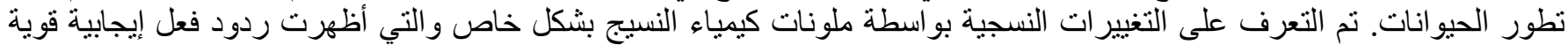

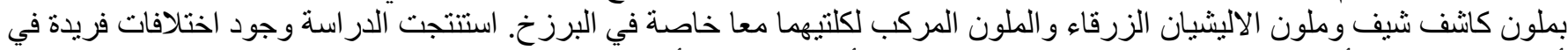

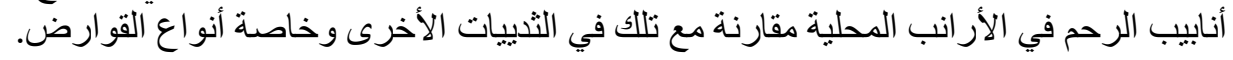




\section{Introduction}

During the last two decades, rabbits were heavily used as an experimental animal model in researches of various morphological anomalies and diseases for the sack of human and animals. They have been used as suitable model in inducing many diseases and subsequent treating approaches focused on many aspects such as toxicology, pharmacology and surgery (1). Accordingly, microscopic structure of different organs of this species is required depth description and exploration and out of which the uterine tubes as an important organ of the female reproductive system. As early as the beginning of the past decade, records of the FAO (2) revealed that rabbit keeping provides additional income and supplies additional protein for poor rural and urban households with low investment and labour inputs. Some reasons caused importance and lead to selection of this animal such as they are source of meat, have small body size, short interval between generations, high reproductive potential, fast growth rate, genetic diversity, and the ability to utilize forages and byproducts as major diet components that make the animal appropriate for small livestock keeping in developing countries (3). Rabbits have a short reproductive cycle and the pregnancy lasts for approximately 31 days, with female sexual maturity occurring at about 4 to 5 months of age depending on breed with ovulation occurring about 10 to 13 hours post coitus (4). In contrast to the huge number of studies on the reproductive tract of birds and domesticated animals few studies on the ontogeny and developmental changes of the rabbit female reproductive organs are available. Most investigations on the pre- and post-hatching development of the reproductive organs were carried out on avian such as hens (5), Mallard (6,7), emu birds (8). Whereas, in domestic animal studies were focused on histomorphology of some organs of the female reproductive tract such as oviduct of golden hamster (9), guinea pig (10), mice (11), oviduct of goat (12), bovine (13) and bitch (14). $\mathrm{Up}$ to date there are no available researches in the previous and the current literatures investigated the developmental changes in the uterine tubes of the female reproductive system in the rabbit (Oryctolagus cuniculus). Based on such reason and the importance of this animal species mentioned in the above introduction, the plan was performed to study the structural developmental changes of the uterine tubes of the rabbits at different postnatal developmental periods that were kitten, immature and mature does stages.

\section{Materials and methods}

\section{Animals and study design}

This research was conducted from March - 2017 to April - 2018 approved by the College Concil of Veterinary Medicine / Baghdad University. Twenty-four female local rabbits (Oryctolagus cuniculus) of three different ages ( 8 for each age) were selected to conduct the present investigation. Kittens of one week of age with apparent healthy condition were purchased directly from rabbit's breeders. Some of the obtained kittens were used directly and others were left for 8 to 10 weeks and euthanized as immature does and for 5 months as mature does (virgin). Animals were under supervision to insure their good healthy condition before their euthanasia and subsequent dissection.

\section{Dissection of animals}

Each selected rabbit was euthanized by intramuscular injection of sodium pentobarbitone $(140 \mathrm{mg} / \mathrm{kg}$ of body weight). The rabbit was placed on dorsal recumbency to view the ventral aspect, thereafter; a mid-line abdominal incision was made to expose the structures in the peritoneal cavity. The reproductive organ exposed and both uterine tubes were observed and photographed in situ and later dissected out. The organs were temporarily kept in glass container to keep them moist in physiological saline solution. Then after each tube was transfer to filter paper to dry before weighing. After their extirpation on board, the length and weight were measured using ruler and thread, weighing balance with a sensitivity of 0.0001 gram, and vernier callipers, respectively (Table 1). The data obtained expressed as mean \pm standard error of the mean (mean \pm SEM). Values of $\mathrm{P}<0.05$ were considered significant. All measurements were listed in tables.

Table 1: Gross measurements of the uterine tubes of the local rabbits at different ages

\begin{tabular}{llrc}
\hline Organ & Different ages & \multicolumn{2}{c}{ Measurements } \\
\cline { 3 - 4 } & of rabbits & Length $(\mathrm{mm})$ & \multicolumn{1}{c}{ Weight $(\mathrm{mg})$} \\
\hline \multirow{2}{*}{ Uterine } & Female kittens & $50.0 \pm 0.31$ & $9.0 \pm 0.03$ \\
tube & Immature does & $210.0 \pm 0.06$ & $50.0 \pm 0.02$ \\
& Mature does & $700.0 \pm 0.04$ & $340.0 \pm 0.01$ \\
\hline
\end{tabular}

\section{Preparation of histological specimens}

The uterine tubes as a whole was dissected and their different regions such as pre-ampulla, ampulla and isthmus were cut out and washed with normal saline and then by $10 \%$ neutral buffered formalin and eventually immersed in $10 \%$ neutral buffered formalin for $72 \mathrm{hrs}$. For future staining with histochemical stains, some specimens were fixed by Bouin's solution. Procedure of routine histological technique was performed to prepare histological sections. General and special stains were used to stains the tissue sections such as hematoxyline-eosin (H\&E), Masson Trichrome (MTC), Gomori Trichrome, Alcian blue (AB) at $\mathrm{pH}$ 2.5, Periodic acid schiff (PAS), combined PAS-AB at $\mathrm{pH} 2.5$ and combined $\mathrm{AB}$ at $\mathrm{pH} 2.5$-Aldehyde fuchine (AF) (15). 


\section{Micromorphometric measurements}

Thickness of tunica mucosa and muscularis in uterine tubes were measured using the colour USB 2.0 digital image system (Scope Image 9.0) which is provided with image processing software. All above parameters were set in table to achieve comparison among different postnatal ages. Tissues sections of $6 \mathrm{~mm}$ thick were stained by Gomori Trichrome stain because this stain facilitates the identification of the different tissues when carrying out micromorphometric measurements (16).

\section{Statistical analysis}

All data of both macromorphometric and micromorphometric measurements were analyzed by oneway ANOVA using SPSS software (version 14).

\section{Results}

\section{Macroscopic findings}

Gross examination revealed the presence of left and right bilateral uterine tubes in the female genital system of kittens, immature rabbits and 5 months aged virgin mature does. The two elongated tubes comprised three distinct regions that were pre-ampulla, ampulla and isthmus. The preampulla coiled around the ovary and it invested with it in the mesovarian. Its diameter appeared slightly thicker than that of the next part, the ampulla. The caudal end continued with the ampulla which was thin and tortuous tube. The remaining part of the uterine tube i.e. the isthmus which was short, straight and joined the cranial part of the uterine horn forming distinctly an area of junction. The mesosalpinx which held the uterine tube was continuous with the mesovarium cranially and the mesometrium caudally (Figure 1).

Morphometrical measurements such as lengths and weights were listed in table 1 . The means of lengths and weights of the uterine tubes of one-week kittens were $50.0 \pm 0.31 \mathrm{~mm}$ and $9.0 \pm 0.03 \mathrm{mg}$, respectively. These measurements were changed into $210.0 \pm 0.06 \mathrm{~mm}$ and $50.0 \pm 0.02 \mathrm{mg}$ in immature does. Similarly, these measurements were jumped into $700.0 \pm 0.04 \mathrm{~cm}$ and $340.0 \pm 0.01 \mathrm{mg}$ in mature does.

\section{Microscopic findings}

The uterine tubes can be divided into three regions by reference to their characteristic diameters and histological features. They were distinguished according to the morphological and micromorphometric differences of their walls into pre-ampulla, ampulla and isthmus (Table 2). Microscopically the wall of uterine tubes was constructed of three different tunicae that were mucosa, muscularis and serosa (free part) or adventitia (attached part to mesosalpinx). The thicknesses of these tunicae were different in the three different regions and in another aspect each region was different at the three different studied aged rabbits i.e. kittens, immature and mature (Table 3). In the tunica mucosa, the epithelial cells of the uterine tube were mixed of ciliated columnar and non-ciliated columnar cells. The latter non ciliated cells were either secretory or nonsecretory (called peg cells). The latter cells were histochemical identified subsequently. Characteristically, the mucosal folds were found in complex pattern. They were different in the three different regions of uterine tube and each region was different at different studied ages of the rabbits.

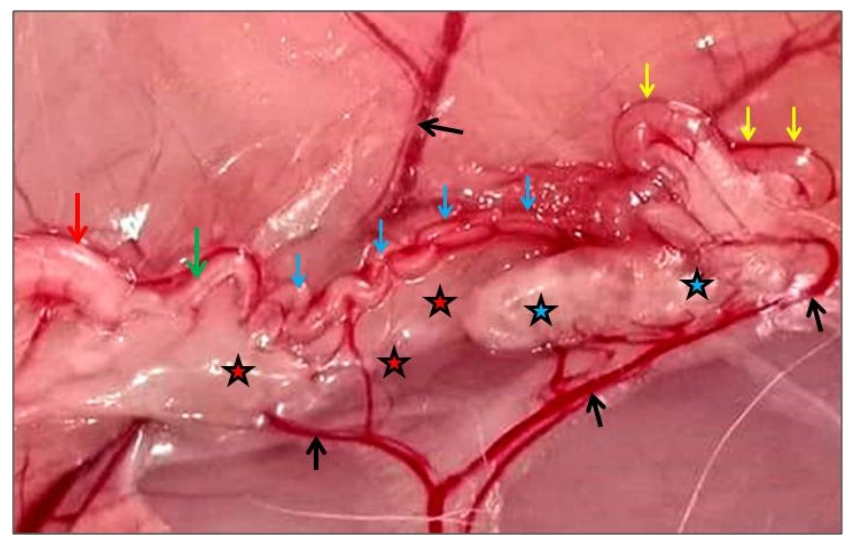

Figure 1: Left uterine tube of the female kitten in situ. It showed pre-ampulla (yellow arrows), ampulla (blue arrows), isthmus (green arrow) joined with uterine horn (red arrow) and mesosalpinx (red stars). The figure showed also left ovary (blue stars) and related blood vessels (black arrows).

Table 2: Micromorphometric measurements (Mean $\pm \mathrm{SE}$ ) showed diameters $(\mu \mathrm{m})$ of the three regions of the uterine tubes in female kittens, immature and mature does

\begin{tabular}{lccc}
\hline \multirow{2}{*}{$\begin{array}{l}\text { Regions of } \\
\text { uterine tubes }\end{array}$} & \multicolumn{3}{c}{ Different ages of female rabbits } \\
\cline { 2 - 4 } & Kittens & $\begin{array}{c}\text { Immature } \\
\text { does }\end{array}$ & $\begin{array}{c}\text { Mature } \\
\text { does }\end{array}$ \\
\hline Preampulla & $345 \pm 0.30$ & $795 \pm 0.78$ & $1059 \pm 0.33$ \\
Ampulla & $327 \pm 0.90$ & $636 \pm 1.01$ & $795 \pm 0.17$ \\
Isthmus & $365 \pm 0.04$ & $980 \pm 0.54$ & $1290 \pm 0.81$ \\
\hline
\end{tabular}

Significant differences between regions of uterine tubes in kittens, immature and mature does. Significant differences between all regions as a whole of uterine tube of immature does compared to those corresponding regions of kittens and mature does.

\section{Uterine tubes of female kittens Pre-ampulla}

The epithelium of the pre-ampulla was simple columnar type and it consists of two kinds of cells, namely ciliated 
and non-ciliated cells. The ciliated type of cells was predominant. Ciliated cells were columnar type of central rounded nuclei and lightly stained cytoplasm. Non ciliated cells were columnar type of elongated darkly stained nuclei basally located. The epithelium was rested on lamina propria of loose connective tissue well supplied by blood vessels. The tunica mucosa was folded and the number of these folds was ranged from 5 to 7 (Table 4). The individual primary mucosal fold was papillary in shape with rounded tip and wider in its middle part. It comprised of a core of loose connective tissue come up from the underlying lamina propria.

Table 3: Micromorphometric measurements (Mean $\pm \mathrm{SE}$ ) showed thicknesses of mucosa, muscularis in each region of the uterine tubes in female kittens, immature and mature does

\begin{tabular}{llccc}
\hline \multirow{2}{*}{ Regions of uterine tube } & \multicolumn{3}{c}{ Different ages of female rabbits } \\
\cline { 2 - 4 } & Mucosa $(\mu \mathrm{m})$ & Kittens & Immature does & Mature does \\
\cline { 2 - 4 } Pre-ampulla & $12.57 \pm 0.08$ & $27.69 \pm 0.40$ & $33.34 \pm 0.44$ \\
& Muscularis $(\mu \mathrm{m})$ & $27.21 \pm 0.10$ & $17.44 \pm 0.11$ & $18.04 \pm 0.10$ \\
& Wall $(\mu \mathrm{m})$ & $41.78 \pm 0.09$ & $47.13 \pm 0.23$ & $51.38 \pm 0.27$ \\
& $\%$ of mucosa/wall & $30.08 \%$ & $58.75 \%$ & $64.88 \%$ \\
& $\%$ of muscularis/wall & $69.92 \%$ & $41.25 \%$ & $35.12 \%$ \\
\hline \multirow{5}{*}{ Ampulla } & Mucosa $(\mu \mathrm{m})$ & $17.95 \pm 0.55$ & $29.51 \pm 0.22$ & $45.37 \pm 0.31$ \\
& Muscularis $(\mu \mathrm{m})$ & $34.44 \pm 0.40$ & $36.76 \pm 0.43$ & $15.23 \pm 0.44$ \\
& Wall $(\mu \mathrm{m})$ & $55.39 \pm 0.48$ & $69.27 \pm 0.09$ & $64.60 \pm 0.38$ \\
& $\%$ of mucosa/wall & $32.40 \%$ & $42.60 \%$ & $70.23 \%$ \\
\multirow{5}{*}{ Isthmus } & 6 of muscularis/wall & $67.60 \%$ & $57.40 \%$ & $29.77 \%$ \\
& Mucosa $(\mu \mathrm{m})$ & $43.90 \pm 0.31$ & $40.45 \pm 0.07$ & $30.60 \pm 0.90$ \\
& Muscularis $(\mu \mathrm{m})$ & $68.93 \pm 0.22$ & $41.73 \pm 0.20$ & $57.45 \pm 0.38$ \\
& Wall $(\mu \mathrm{m})$ & $34.67 \%$ & $85.18 \pm 0.33$ & $91.05 \pm 0.62$ \\
& $\%$ of mucosa/wall & $65.33 \%$ & $47.48 \%$ & $33.60 \%$ \\
\hline
\end{tabular}

The percentage of mucosal thickness was increased on the expanse of muscularis thickness and vice versa. The total thickness of mucosa plus muscularis was increased in the direction extended from pre-ampulla toward isthmus in all studied ages. The thicknesses of mucosae in pre-ampulla and ampulla were increased with the advanced ages as in immature and mature does. The mucosal thickness was highest at isthmus in the immature does compared to those of female kittens and mature does. In female kittens, the percentage of mucosal thickness was increased non significantly in the direction extended from the preampulla toward the isthmus, whereas, in contrary, the percentage of muscularis thickness was decreased.

Table 4: Micromorphometric measurements of the primary mucosal folds in each region of the uterine tubes in female kittens, immature and mature does

\begin{tabular}{llccc}
\hline \multirow{2}{*}{ Measurements } & \multirow{2}{*}{ Regions of uterine tube } & \multicolumn{3}{c}{ Different ages of female rabbits } \\
\cline { 3 - 5 } & & Kittens & Immature does & Mature does \\
\hline \multirow{3}{*}{ Length $(\mu \mathrm{m})$} & Pre-ampulla & $102.64 \pm 0.71$ & $338.88 \pm 0.22$ & $421.35 \pm 0.05$ \\
& Ampulla & $95.96 \pm 0.29$ & $169.85 \pm 0.42$ & $187.41 \pm 0.30$ \\
& Isthmus & $67.50 \pm 0.11$ & $105.24 \pm 0.07$ & $133.24 \pm 0.65$ \\
\hline \multirow{2}{*}{ Width $(\mu \mathrm{m})$} & Pre-ampulla & $40.84 \pm 0.02$ & $50.86 \pm 0.23$ & $57.67 \pm 0.33$ \\
& Ampulla & $57.09 \pm 0.11$ & $79.04 \pm 0.11$ & $81.53 \pm 0.04$ \\
& Isthmus & $67.61 \pm 0.08$ & $87.92 \pm 0.07$ & $98.85 \pm 0.12$ \\
\hline \multirow{2}{*}{ Number of folds (range) } & Pre-ampulla & $5-7$ & $10-13$ & $13-17$ \\
& Ampulla & $4-6$ & $6-7$ & $6-8$ \\
& Isthmus & $4-6$ & $4-7$ & $4-6$ \\
\hline
\end{tabular}

Lengths of primary mucosal folds were longest in pre-ampulla compared to those of ampulla (lower) and in isthmus (lowest) in all studied ages of female rabbits. Widths of mucosal folds were widest in isthmus compared to those in ampulla (lower) and in pre-ampulla (lowest) in all studied ages of female rabbits. Number of primary mucosal folds in the pre-ampulla significantly increased in immature and mature does compared to those in kittens but not significantly in cases of ampulla and isthmus. Lengths of folds in pre-ampulla in the immature and mature does significantly increased compared to those in kittens. 
The tunica muscularis was thicker than mucosa structured by few layers of circularly arranged smooth muscle fibers. Tunica serosa was very thin layer of loose connective tissue covered by mesothelium present at the free border of the tube but in contrary the attached border to the mesosalpinx showed thick layer of loose connective tissue filled with large number of blood vessels with the presence of adipose tissue (Figure 2A).

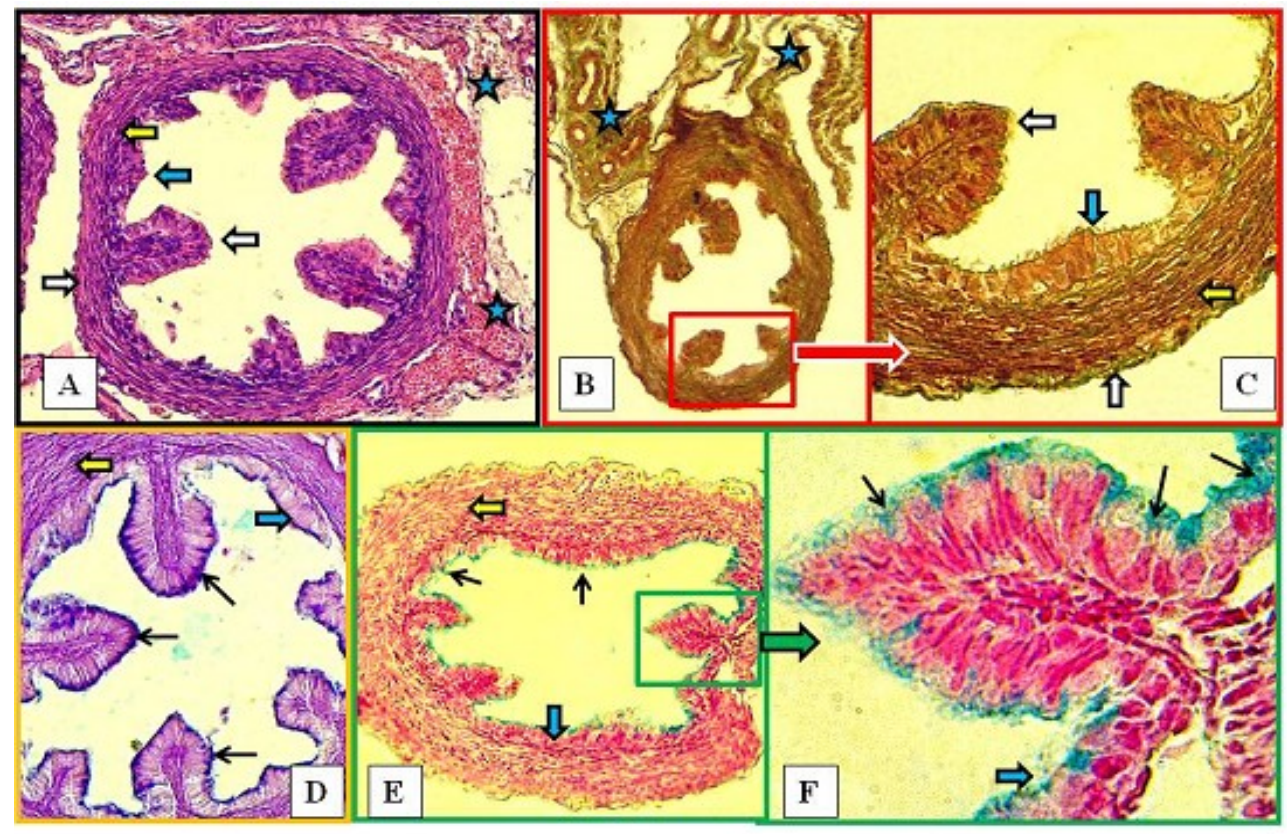

Figure 2: Uterine tube of female kitten showed pre-ampulla (A: H\&E, X20), ampulla (B-C: MTC, X10 \& X40) and isthmus [D: AB-PAS (+), E-F: AB (+)] regions. The wall was constructed of mucosa (blue arrows), muscularis (yellow arrows), serosa (white arrows) with the mesosalpinx rich with blood vessels (blue stars). Black arrows shows positive reactions.

\begin{abstract}
Ampulla
Similarly, to the pre-ampulla part, the epithelium of the ampulla was simple columnar which consists of two kinds of cells (ciliated and non-ciliated cells). The number of ciliated type of cells was also predominant. The tunica mucosa showed primary folds with a number ranged from 4 to 6, lesser number compared to those counted in preampulla (Table 4). The diameter was slightly lesser than that of pre-ampulla. The tunica muscularis was similar to what was found in pre-ampulla composed of circularly arranged smooth muscle fibers. Similarly, to pre-ampulla, the muscularis was thicker than that of mucosa. The attached border of ampulla to the mesosalpinx showed relatively lesser number of blood vessels (Figure 2B, 2C).
\end{abstract}

\section{Isthmus}

It showed similar histological structure to the ampulla with same number of primary mucosal folds but they were wider and shorter in lengths. Similarly, to pre-ampulla, the muscularis was thicker than that of mucosa (Figures 2D, $2 \mathrm{E}, 2 \mathrm{~F})$. The diameter was slightly higher than those of preampulla and certainly the ampulla (Table 2).

\section{Uterine tubes of immature does \\ Pre-ampulla}

Microscopic examination of the wall of the pre-ampulla in immature does showed few morphological and morphometric differences compared to what was recorded in kittens. The mucosa showed predominant columnar ciliated cells with lower number of non-ciliated columnar epithelial lining cells most of them were peg cells and few of them showed apical granules and such findings will be described subsequently in the histochemical results. The lamina propria of loose connective tissue extended up into the primary mucosal folds forming their cores. The primary mucosal folds were very long in length and showed secondary folds. These folds extended extensively into the lumen of the pre-ampulla occluding it by forming a labyrinth. The muscularis was composed of circularly arranged smooth muscle fibers ( 2 to 4 layers) but this tunic was thinner than the mucosa, a result oppositely recorded previously in kittens for the same region (Figures 3A, 3B, $3 \mathrm{C})$. The mucosa was thicker than the muscularis. The total thickness of the wall was thicker than that recorded in kittens. The diameter of pre-ampulla in this age was greater significantly than that of kittens (Tables 2,3). 

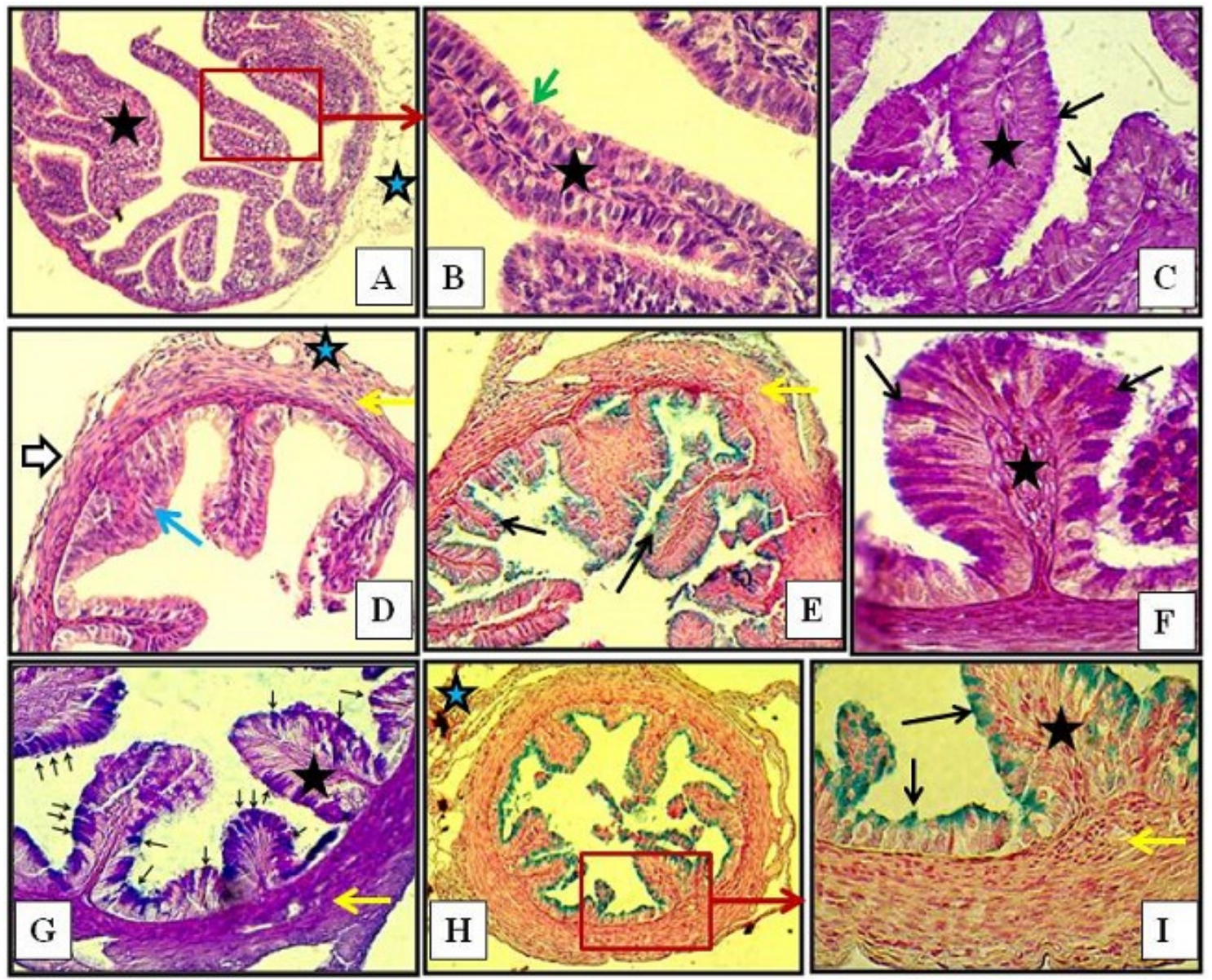

Figure 3: Uterine tube of immature does showed pre-ampulla (A: H\&E, X10. B: H\&E, X40; C: PAS, X40), ampulla (D: H\&E, X20. E: AB, X10. F: PAS, X40) and isthmus (D: AB-PAS (+)ve, X40. H: AB (+)ve, X10. I: AB, X40). The wall was constructed of mucosa (blue arrows), muscularis (yellow arrows), serosa (white arrows) with the mesosalpinx rich with blood vessels (blue stars). Black arrows show positive reactions. Green arrows showed ciliated and non ciliated cells on mucosal fold (black stars).

\section{Ampulla}

The mucosa of ampulla in immature does showed approximately equal number of ciliated and non-ciliated columnar epithelial lining cells most of them were secretory cells by reference to their apical granules and such findings will be described subsequently in the histochemical findings. The primary mucosal folds were long papillary in shape but they were shorter significantly compared to those found in the pre-ampulla. They were free of secondary folds which observed in pre-ampulla. Tunica muscularis was thicker than that of pre-ampulla of 5 to 8 smooth muscle fibers layers. In contrary to the pre-ampulla, this tunic was thicker than the mucosa (Figure 3D, 3E, 3F). The diameter and the total wall thickness of ampulla of immature does were higher than those recorded in the same region in female kittens.

\section{Isthmus}

Microscopic examination of the wall of the isthmus of the immature does showed mucosa of numerous non ciliated secretory cells with a smaller number of ciliated cells present in between. The primary mucosal folds were similar in their number and shapes to those of ampulla but they were shorter in their lengths and wider in widths (Table 4). The thickness of tunica muscularis was approximately equal to the mucosal thickness but differently to the other regions, this region showed thin inner longitudinally arranged smooth muscle fibers and thicker outer circularly arranged smooth muscle fibers (Figure 3G, 3H, 3I; Figure 4). The diameter and the total wall thickness of isthmus of immature does were higher than those recorded in the same region in female kittens (Table 2, 3). 


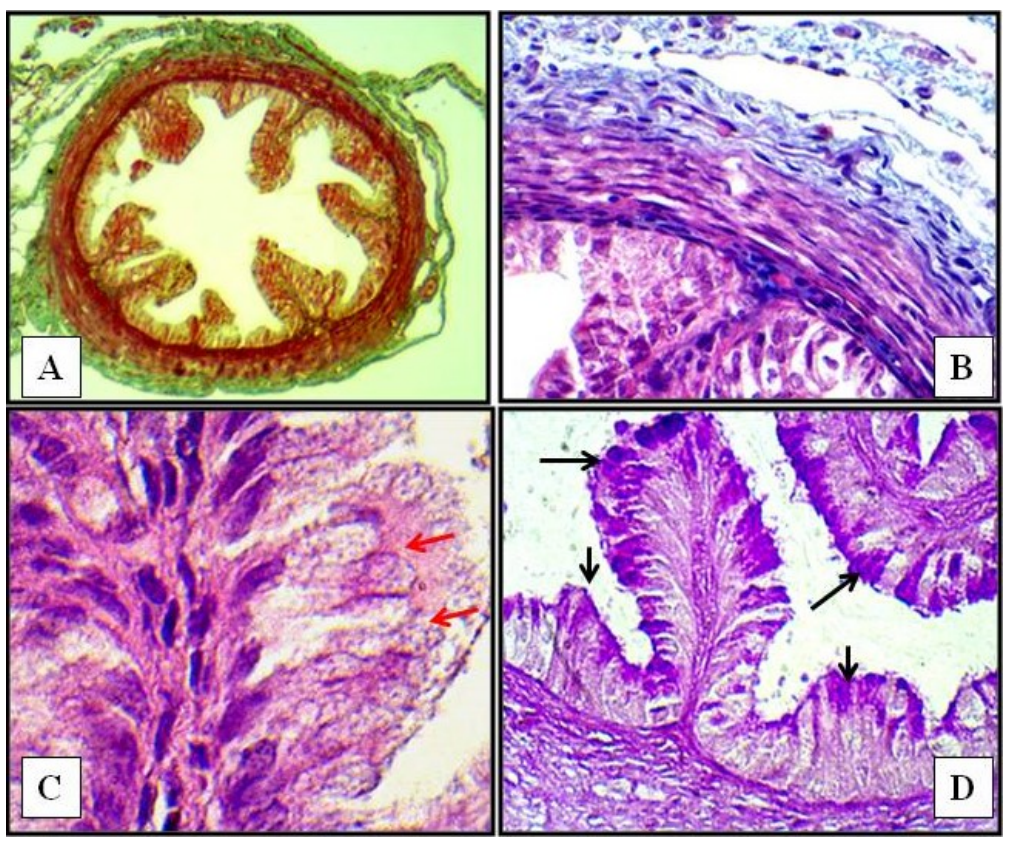

Figure 4: Isthmus of uterine tube of immature does. A: Gomori Trichrome, X10. B: MTC, X40. C: H\&E, X1000. D: PAS (+) ve (black arrows), X40. Red arrows show secretory cells.

\section{Uterine tubes of mature does Pre-ampulla}

Microscopic examination of the pre-ampulla in mature does showed structural similarities to those of the same region in immature does. The mucosa constructed of predominantly ciliated columnar cells and for lesser extent non ciliated cells which were demonstrated histochemical negative indicated absence of secretory secretion in another speaking they were peg cells. The primary mucosal folds were longer and wider than those observed in the preampulla of immature does with the presence of secondary folds. As same as to the immature does, the thickness of mucosa appeared thicker than that of muscularis. The total wall thickness was thicker than those recorded in immature does and female kittens. In fact, the thicknesses of mucosa and muscularis were slightly thicker than their corresponding in immature does. Similarly to those of immature does, the muscularis was thin and constructed of some circularly arranged smooth muscle bundles (Tables 3 , 4).

\section{Ampulla}

Histologically, the ampulla showed smaller diameter than that of pre-ampulla. Its wall was constructed of thicker mucosa and thinner muscularis. The lining epithelium was formed predominantly of ciliated columnar cells and a smaller number of non-ciliated cells in between them. The latter type of cells was negatively stained with histochemical staining procedures, a data will be described subsequently in the histochemical results. This fact indicated absence of secretory functions so they considered non secretory columnar or peg cells. The primary mucosal folds were shorter in length and lesser in number compared to those present in pre-ampulla. Tunica muscularis was thin and formed of few circularly arranged smooth muscle bundles. The tube was covered externally by thin serosa and thick adventitia at its free border and attached border to the mesosalpinx, respectively (Tables 3,4 ).

\section{Isthmus}

Microscopic examination of the isthmus in mature does showed that the wall was constructed of thinner mucosa and thick muscularis and such records were opposite to those observed in the wall of ampulla. In fact, the thickness of muscularis was thickest compared to those of the same regions in immature does and kittens. The increased thickness was caused by the presence of inner longitudinal and outer circularly arranged smooth muscle bundles. The lining epithelium of the mucosa was built up by numerous non ciliated columnar (secretory cells) and for lesser extent columnar ciliated cells. Underlying lamina propria of loose connective tissue extended up to form the cores of the mucosal folds. The primary mucosal folds were shorter in length and wider in width compared to those of the ampulla region of the uterine tube (Table 4). As same as to the ampulla, the isthmus was surrounded externally by serosa or adventitia at its free or attached border to the mesosalpinx, respectively (Figure 5). 


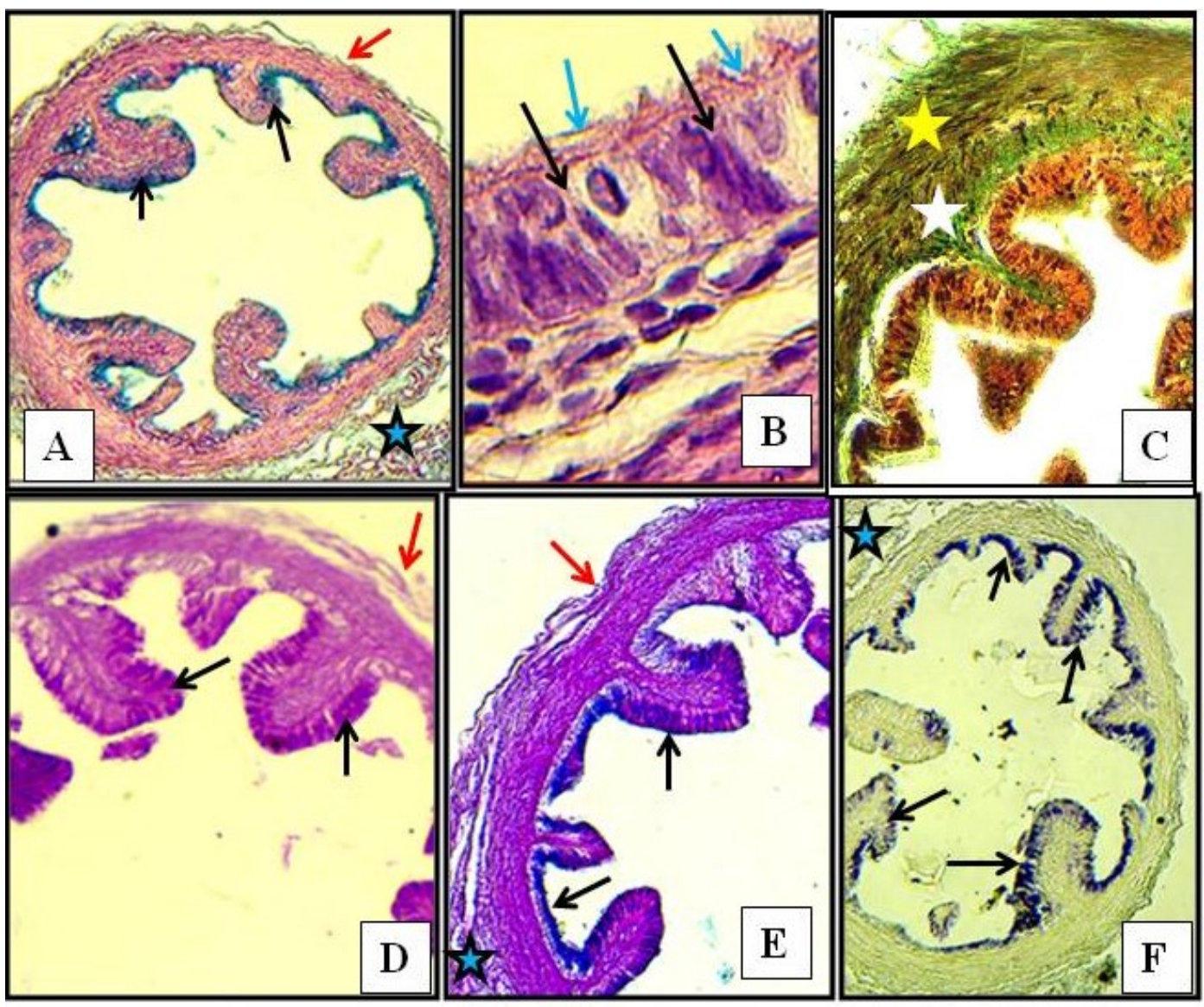

Figure 5: Isthmus of mature does showed A: AB (+)ve, X10. B: H\&E, X40. C: MTC, X20. D: PAS(+)ve, X40. E: AB-PAS $(+)$ ve, $\mathrm{X} 20$. F: AB-AF(+)ve, X10. The figure show also secretory cells (black arrows), ciliated cells (blue arrows), serosa (red arrows), muscularis interna (white star), muscularis externa (yellow star) and mesosalpinx (blue stars).

\section{Histochemical staining of uterine tubes Female kittens}

Staining with MTC stain, the wall of uterine tube of female kittens showed very thin layer of loose connective tissue lamina propria underneath the lining epithelium and very thin serosa of loose connective tissue at its free border and thick filled with numerous blood vessels at its attached border to the mesosalpinx. Also, fine connective tissue fibers were observed intervening between muscular bundles of the tunica muscularis (Figure 2B, 2C).

Post-staining with $\mathrm{AB}$ at $\mathrm{pH} 2.5$ staining procedure, the wall of uterine tube showed at its pre-ampulla and ampulla negative reaction or even slight reaction in some nonciliated cells, respectively. These reactions indicated the presence of non-secretory non-ciliated epithelial cells which can be named peg cells. Distinctly, in the isthmus positive reaction was recorded represented by the presence of bright bluish coloured apical secretory granules in the non-ciliated epithelial cells at mucosa and mucosal folds. These cells were possessed acidic mucopolysaccharides secretory granules. In fact, these positively reacted cells were predominant with sparse adjacent ciliated cells. In contrary, ciliated cells were predominant at both preampulla and ampulla regions.

In addition to that, findings after staining with PAS procedure showed positive reaction toward the stain in the mucosa and almost in the mucosal folds of the isthmus region of the uterine tubes of the female kittens. It showed apical purple granules in its lining non ciliated cells. This fact indicated the presence of neutral mucopolysaccharides secretory granules. The reaction was lesser compared to that with the $\mathrm{AB}$ at $\mathrm{pH} 2.5$ staining procedure. These findings revealed the presence of predominant acidic and for lesser extent neutral secretory granules in the lining epithelium of the isthmus which was well confirmed by combined PAS-AB at $\mathrm{pH} 2.5$ staining procedure. The procedure showed magenta coloured apical granules in the non-ciliated epithelial cells predominantly on mucosal folds (Figure 2D, 2E, 2F). 
In contrary to the above findings, negative reactions were recorded in both pre-ampulla and ampulla regions of the uterine tubes of female kittens. The non-ciliated cells were sparse compared to the ciliated type of cells and they were not possessed any of the secretory granules that were recorded in the isthmus. These non-ciliated were non secretory cells so that they can be called peg cells.

\section{Immature does}

Post staining with MTC stain or Gomori Trichrome stains, the uterine tubes in immature does showed very thin lamina propria of loose connective tissue which was extended upward forming the cores of mucosal folds and thin layer of loose connective tissue serosa at its free border, whereas, thicker layer of loose connective tissue filled obviously with blood vessels at its attached border to the mesosalpinx (Figure 3, 4).

In immature does, the pre-ampulla showed slight reaction toward the PAS staining procedure observed mainly on the mucosal folds, but in contrary was negatively reacted toward $\mathrm{AB}$ at $\mathrm{pH} 2.5$ stain (Figure 3C). In the ampulla, moderate positive reaction toward $\mathrm{AB}$ at $\mathrm{pH} 2.5$ and PAS stains observed in cells of mucosa and mucosal folds by the presence of bluish and purple secretory granules, respectively (Figure 3E, 3F). Such results were confirmed by the combined PAS-AB at $\mathrm{pH} 2.5$ staining procedure. In the last region of the uterine tube i.e. isthmus, obvious reaction detected with $\mathrm{AB}$ at $\mathrm{pH} 2.5$ staining procedure in both mucosal and mucosal folds epithelia which was presented by bluish coloured apical granules. Most of the lining epithelial cells of the isthmus were non ciliated secretory cells, whereas, the ciliated cells were scantily existed. In addition, moderate positive cells with PAS stain was recorded in the isthmus lining which showed purple coloured apical granules. However, the combined PAS-AB at pH 2.5 showed positively the magenta coloured granules in cells existed in the lining epithelia of both mucosa and mucosal folds. In fact, the bluish granules with $\mathrm{AB}$ indicated the presence of acidic mucopolysaccharides and the purple coloured granules with PAS indicated the presence of neutral type of mucopolysaccharides (Figure $3 \mathrm{G}, 3 \mathrm{H})$.

\section{Mature does}

Post staining with MTC stain or Gomori Trichrome stains, the uterine tubes in mature does showed very thin lamina propria of loose connective tissue and thin layer of loose connective tissue serosa at its free border, whereas, thicker layer filled characteristically with blood vessels at its attached border to the mesosalpinx (Figure 5C).

Similarly, to the previous studied ages (kittens and immature does), negative reactions were recorded in the pre-ampulla and very slight positive reaction in some lining cells of ampulla toward both PAS and AB at pH 2.5 as well as combined PAS - $\mathrm{AB}$ at $\mathrm{pH} 2.5$ staining procedures. In the isthmus, distinct positive reaction was recorded in the above procedure techniques. The $\mathrm{AB}$ positive cells were detected mainly on the mucosal folds, whereas, the PAS positive cells were found in the mucosal lining which indicated the presence of acidic and neutral mucopolysaccharides granules, respectively. The type of acidity of those $\mathrm{AB}$ positive secretory cells was confirmed by combined AB-AF staining technique which showed positive reaction indicated the existence of sulphated acidic granules (Figure 5A, 5D, 5E, 5F).

\section{Micromorphometric measurements of uterine tubes}

Micromorphometric measurements such diameters of tubes, thicknesses of mucosa and muscularis, length and number of mucosal folds of different regions of uterine tubes, in different studied ages of female rabbits were well listed in tables 2 and 3. The diameters of pre-ampulla, ampulla and isthmus in female kittens were $345 \pm 0.30$, $327 \pm 0.90$ and $365 \pm 0.04$, respectively, whereas changed in the immature does up to $795 \pm 0.78,636 \pm 1.01$ and $980 \pm 0.54$, respectively for the same regions. Same measurements to the corresponding regions were jumped to $1059 \pm 0.33$, $795 \pm 0.17$ and $1290 \pm 0.81$, respectively in case of mature does (Table 2).

The above data showed significant differences of diameter between the regions of uterine tube in female kittens, immature and mature does. In addition to that, the data revealed significant differences between all regions as a whole of uterine tube of immature does compared to those corresponding regions of kittens and mature does.

Micromorphometric measurements of the thicknesses of mucosa and muscularis in each region of the uterine tubes in female kittens, immature and mature does were listed in Table 3. The data revealed that the percentage of mucosal thickness was increased on the expanse of muscularis thickness and vice versa. The total thickness of mucosa plus muscularis was increased in the direction extended from pre-ampulla toward isthmus in all studied ages. The thicknesses of mucosae in pre-ampulla and ampulla were increased with the advanced ages as in immature and mature does. In the isthmus, the mucosal thickness was highest in the immature does compared to those of female kittens and mature does.

In the female kittens, the morphometric data showed that the thicknesses of mucosa and muscularis in the preampulla were $12.57 \pm 0.08$ and $27.21 \pm 0.10$ so that the total thickness of them was $41.78 \pm 0.09$, resulted lower percentage of mucosa $30.08 \%$ than the muscularis $69.92 \%$. The mucosal and muscularis thicknesses in ampulla were raised into $17.95 \pm 0.55$ and $34.44 \pm 0.40$, respectively. Accordingly, the total thickness of them was $55.39 \pm 0.48$ with lower percentage of mucosa $32.40 \%$ than the muscularis $67.60 \%$. In the isthmus, the thicknesses of 
mucosa and muscularis were further raised into $23.90 \pm 0.31$ and $43.03 \pm 0.22$, respectively, so that the total thickness of them was $68.93 \pm 0.27$ with lower percentage of mucosa $(34.67 \%)$ than the muscularis $(65.33 \%)$. The percentage of mucosal thickness was increased non significantly in the direction extended from the pre-ampulla, ampulla toward the isthmus, whereas, in contrary, the percentage of muscularis thickness was decreased.

Data of immature does show the thicknesses of mucosa in pre-ampulla $27.69 \pm 0.40$ and muscularis $17.44 \pm 0.11$ so that the total thickness of them was $47.35 \pm 0.23$, resulted higher percentage of mucosa $58.74 \%$ than the muscularis $41.25 \%$. The mucosal and muscularis thicknesses in ampulla were $29.51 \pm 0.22$ and $36.76 \pm 0.43$, respectively, so that the total thickness of them was $61.27 \pm 0.09$ with lower percentage of mucosa $42.60 \%$ than the muscularis $57.40 \%$. In the isthmus, the thicknesses of mucosa and muscularis were $40.45 \pm 0.07$ and $41.73 \pm 0.20$, respectively. So that the total thickness of them was $85.18 \pm 0.33$ with lower percentage of mucosa $47.48 \%$ than the muscularis $52.52 \%$ (Table 2).

Micromorphometric data of mature does showed the thicknesses of mucosa in pre-ampulla $33.34 \pm 0.44$ and muscularis $18.04 \pm 0.10$ so that the total thickness of them was $51.38 \pm 0.27$, resulted higher percentage of mucosa $64.88 \%$ than the muscularis $35.12 \%$. The mucosal and muscularis thicknesses in ampulla were $45.37 \pm 0.31$ and $15.23 \pm 0.44$, respectively, so that the total thickness of them was $64.60 \pm 0.38$ with lower percentage of mucosa $70.23 \%$ than the muscularis $29.77 \%$. In the isthmus, the thicknesses of mucosa and muscularis were $30.60 \pm 0.90$ and $57.45 \pm 0.38$, respectively, so that the total thickness of them was $91.05 \pm 0.62$ with lower percentage of mucosa $33.60 \%$ than the muscularis $66.40 \%$.

Micromorphometric measurements in Table 4 showed the length, width and number of mucosal folds that were mostly papillary in shape in each region of the uterine tubes in the female kittens, immature and mature does. Lengths of mucosal folds were longest in pre-ampulla compared to those of ampulla (lower) and in isthmus (lowest) in all studied ages of female rabbits. In addition to that, lengths of pre-ampulla in the immature and mature does were significantly increased compared to those in kittens. The lengths of these folds in pre-ampulla, ampulla and isthmus of kittens were in order $102.64 \pm 0.71,95.96 \pm 0.29$ and $67.50 \pm 0.11$ and in immature does were $338.88 \pm 0.22$, $169.85 \pm 0.42$ and $105.24 \pm 0.07$, respectively. Whereas, in mature dose the correspondingly measurements were $421.35 \pm 0.05,187.41 \pm 0.30$ and $133.24 \pm 0.65$ SE. Widths of mucosal folds were widest in isthmus compared to that in ampulla (lower) and in pre-ampulla (lowest) in the three studied ages of female rabbits. The widths of these folds in kittens pre-ampulla, ampulla and isthmus were in order $40.84 \pm 0.02,57.09 \pm 0.11$ and $67.61 \pm 0.08$ and in immature does were $50.86 \pm 0.23,79.04 \pm 0.11$ and $87.92 \pm 0.07$, respectively. Whereas, in mature dose the correspondingly measurements were $57.67 \pm 0.33, \quad 81.53 \pm 0.04$ and $98.85 \pm 0.12$ SE.

The number of mucosal folds in the pre-ampulla significantly increased in immature and mature does compared to those in kittens but not significantly in cases of ampulla and isthmus (Table 3). The number of mucosal folds in pre-ampulla, ampulla and isthmus of uterine tubes in kittens were 5-7, 4-6 and 4-6, respectively, whereas, in immature does the ranges were 10-13, 6-7 and 4-7 for the same regions. The range of number of these folds was slightly different in mature does 13-17, 6-8 and 4-6, respectively.

\section{Discussion}

The gross findings of the uterine tubes in female kittens, immature and mature does showed long tubular organs, coiled in their cranial regions, very long and tortuous in their middle regions, short and more straighten in their caudal regions. They were joined caudally to the cranial ends of the corresponding uterine horns gradually without intramural tubal projections into the cavities of horns which were recorded in other species such as African giant rats as uterine intramural portion (17). In fact, the name of the three regions of the uterine tube that were pre-ampulla, ampulla and isthmus was based mainly upon gross features and confirmed certainly by the microscopic examination. Other references divided the mammalian uterine tube into three different anatomical regions that were infundibulum, ampulla and isthmus; each one of them is associated with distinct physiological functions $(18,19)$. The reference considered the rostral portion of the infundibulum as fimbriae which appeared responsible for oocyte transport into the uterine tube after ovulation. In addition, different names were given to the different regions of the oviduct in the mammalian species as fimbriae, ampulla, isthmus and utero-tubal junction (20).

Absence of the prominent uterotubal junction in studied local rabbits which was dissimilar to other animal species may be due to its different physiological function. In bovine species it has been mentioned that this part together with isthmus were implicated in the events of sperm transportation such as storage and capacitating that were required for preservation of motility, viability and fertilizing ability of spermatozoa (21).

Current findings revealed that the ampulla was the longest region, whereas the pre-ampulla was shorter and the isthmus region was the shortest but the larger in diameter. Such differences may be due to the different possible events takes place in these regions. The longest length of ampulla gave greater chance for fertilization of the coming female gametes from the pre-ampulla where only site of 
completing of the second meiosis. The larger diameter of isthmus may give a chance for the storage of greater number of spermatozoa (22).

Lengths of uterine tubes of the female kittens, immature and mature does were $0.50,2.10$ and $7 \mathrm{~cm}$, respectively which were different compared to those recorded in the adult African giant rat. In this animal species, the mean length of the uterine tube was $4.44 \pm 0.06 \mathrm{~cm}$ which appeared shorter than the mature age of studied local rabbits (17). Also, the lengths were different and appeared longer than those previously recorded in the laboratory rat $2.4 \mathrm{~cm} \mathrm{(23)} \mathrm{but} \mathrm{were} \mathrm{approximately} \mathrm{similar} \mathrm{to} \mathrm{those} \mathrm{of} \mathrm{the}$ mixed breed rabbit $(6.00 \pm 0.794 \mathrm{~cm})$ documented by Bitto et al. (24).

The beginning portion of uterine tubes (pre-ampulla) in female kittens, immature and mature does was bigger in diameter with thinner wall than the next portion the ampulla and such picture was not parallel with same region described previously in the uterine tubes of the large animals as in the cow appeared funnel-shaped with a wide and a narrow sides so that the first part was called infundibulum (17).

Data of microscopic examination showed three regions of the uterine tubes of the three studied ages of the local rabbits. Accurate conclusion to their walls indicated that uterine tubes of kittens were not fully developed. The tubes histology showed slight differences between these three regions. Actually, the wall developed under hormonal effects that were ovarian hormones. However, the histochemical staining procedures that were applied identified non ciliated cells in the lining epithelium of isthmus only as secretory cells, whereas, not in ampulla and pre-ampulla. This fact indicated that the isthmus in the female rabbits is very important and the organ starts to develop as early as in kitten period.

In immature does, global histological changes were takes place so that the three different regions were easily identified or histologically recognized and the histochemical procedures showed positive reactions ranged from slight, moderate and strong in the pre-ampulla, ampulla and isthmus, respectively. The latter region was obviously reacted with histochemical stains such as PAS, combined PAS-AB, combined AB-AF indicated its faster and earlier development for the subsequent requirement in the advanced age of life of this animal. These changes in the uterine tubes of the immature does may be takes place in relationship with the ovarian follicles and the development of granulosa and theca interna endocrine cells.

In mature does, similar changes to those in immature does but the histochemical reactions were more prominent and highly apparent in the isthmus in which the $\mathrm{AB}$ positive cells were detected mainly on the mucosal folds, whereas, the PAS positive cells were found in the mucosal lining which indicated the presence of acidic and neutral mucopolysaccharides granules, respectively. The type of acidity confirmed by combined $\mathrm{AB}-\mathrm{AF}$ staining technique which showed positive reaction indicated the existence of sulphated acidic granules. Similarly, these sulphated acidic granules were also recorded in the female goat uterine tubes (25). In fact, current findings showed more neutral mucopolysaccharides granules in the cranial regions whereas, more sulphated acidic at the caudal region, i. e the isthmus which were in accordance with findings of Ozen et al. (26) in Angora rabbit. In many mammals, the epithelial cells showed marked regional variations in their uterine tubes. These variations were in their ultrastructural, histochemical and physiological features (20).

In mature does the secretory cells were moderately developed in the uterine tubes which may aid the processes of gametes fertilization and embryonic development. These facts were similarly recorded in domestic mammals where the uterine tube known to plays a central role in successful reproduction, transport ovum and sperm to the site of fertilization (22). In does the isthmus appeared very characteristically developed to be suitable sperm's reservoir as early as kitten and immature does stages of their life which may be under the effects of maternal hormones or the ovarian follicular hormones, respectively. The differences of development of the regions of does uterine tubes comes in agreement with previous studies of Alhasani et al. (27) about the same animal species who believed that uterine tube act as transited passage for immediate function to fertilize oocyte and transport it toward the uterus. This reference recorded after salpingectomy in rabbit no effect on implantation does takes place. It looks like in the rabbit; the oviduct role is an immediate on the periovulatory and perifertilzation nature. These differences may be due to the nature of anatomic connection of its oviduct with the ovary. The existence of three different types of epithelial cells in the lining epithelium of the uterine tubes of the studied female rabbits (ciliated, secretory and peg cells) was in accordance with the previous records of Cheng and Bostwick (28). Regarding the isthmus, previous references postulated the importance of this organ in the transportation, maturation, capacitating and nutrition of the coming sperms post coitus or mating (18-21).

\section{Conclusion}

Current study recorded differences in both macroscopic and microscopic as well as morphometric aspects of the uterine tubes of the local rabbits compared to other animal species, specifically the species belong to rodent's family. The study findings were in agreement and confirmed previous records and postulations of (29) and (30-33) that rabbits were different from rodents in their organs anatomically, histologically and histochemically. 


\section{Conflict of Interests}

The authors have not declared any conflict of interests.

\section{Acknowledgement}

The authors strongly acknowledge the council of the Veterinary Medicine College / Baghdad University to support this research project

\section{References}

1. Abidu-Figueiredo, Xavier-Silva M, Cardinot B, Babinski TM, MA, Chagas MA. Celiac artery in New Zealand rabbit: Anatomical study of its origin and arrangement for experimental research and surgical practice. Pesq Vet Bras. 2009;28(5):237-240. http://dx.doi.org/ $10.1590 /$ S0100-736X2008000500002

2. FAO. FAO recognizes the increasingly important role of rabbit breeding: Global rabbit production exceeds 1 million tons. Rome; FAO Press; 2001. http://www.fao.org/WAICENT/OIS/PRESS NE/PRESSENG/2001/pren0157.htm

3. Cheek PR. Potentials of rabbit production in tropical and subtropical agricultural systems. J Anim Sci. 1968;63:1581-1586. DOI: $10.2527 /$ jas $1986.6351581 x$

4. Gad SC. Animal models in toxicology. $3^{\text {rd }}$ ed. Philadelphia: CRC Press; 2016. $438 \mathrm{p}$

5. Mohammadpour AA, Zamanimoghadam A, Heidari M. Comparative histomorphometrical study of genital tract in adult laying hen and duck. Vet Res Forum. 2012;3(1):27-30.

6. Al-Saffar FJ, Abood DA. Histomorphological study of the pre hatching development of the female genital system in Indigenous Mallard Duck (Anas platyrhynchos). Inter J Adv Res. 2014;10:248263.

7. Abood DA, Al-Saffar FJ. The post hatching development of the female genital system in Indigenous Mallard Duck (Anas platyrhynchos). Iraqi J Vet Med. 2016;39(2):17-25.

8. Vijayakumar K, Paramasivan S, Madhu N. Histological and histochemical observations on oviduct of laying and non -laying emu birds (Dromaius novaeholiandlae). Inter J App Sci Res. 2016;6(4):8996.

9. Abe H , Oikawa T. Differentiation of the golden hamster oviduct epithelial cells during postnatal development: an electron microscopic study. J Exp Zool. 1989;252:43-52. https://doi.org/10.1002/jez. 1402520107

10. Lydrup ML, Hellstrand P. Rate of oxidative and glycolytic metabolism in the guinea-pig oviduct in relation to contractility and hormonal cycle. Acta Physiol Scand. 1986;128(4):525-533. DOI: $10.1111 / \mathrm{j} .1748-1716.1986 . t b 08008 . x$

11. Stewart CA, Behriner RR. Mouse oviduct development. Res Probl Cell Differ. 2012;55:247-262. DOI: 10.1007/978-3-642-30406-4_14.

12. Abe H, Onodeera M, Sugawara S, Satoh T, Hoshi H. Ultrastructural features of goat oviductal secretory cells at follicular and luteal phases of the estrous cycle. J Anat. 1999;195:515-521. DOI: 10.1046/j.14697580.1999.19540515.x

13. Yaniz, JL, Gatius FL, Santolaria P, Mullin AJ. Study of the functional anatomy of bovine oviductal mucosa. Anat Rec. 2000;260:268-278. DOI: $\mathrm{AR} 60>3.0 . \mathrm{CO} ; 2-\mathrm{L}$

14. Steinhauer N, Boos AAR, Günzel-Apel A-R. Morphological changes and proliferative activity in the oviductal epithelium during hormonally defined stages of the oestrous cycle in the bitch. Reprod
Domest Anim. 2004;39(2):110-9. DOI: 10.1111/j.1439-0531.2004. 00490.x

15. Luna G. Manual of Histological Staining Methods of the Armed Forced Institute of pathology. $3^{\text {rd }}$ ed. New York: McGraw Hill Book; 1968. 71-74 p.

16. Wei S, Bai J, Gong Z, Ma W, Wei M . GnRH agonist active immunization influences ovarian development and GnRH receptor mRNA expression levels of pituitary in Japanese white rabbits (Oryctolagus cuniculus). Livest Sci. 2011;139(3):222-229. https://doi.org/10.1016/j.livsci.2011.01.015

17. Ali MN, Onyeanusi BI, Ojo SA, Ayo JO, Maidawa SM, Imam J. Biometric and morphologic studies of the female reproductive organs of the African giant rat (Cricetomys gambianus: Waterhouse). Folia Morphol. 2010;69(4):213-215.

18. Hunter RHF. Pre-ovulatory arrest and peri-ovulatory distribution of competent spermatozoa in the isthmus of the pig oviduct. J Reprod Fertil. 1984;72:203-211. DOI:10.1530/jrf.0.0720203

19. Suárez SS. Sperm transport and motility in the mouse oviduct: Observations In situ. Biol Reprod. 1987;36:203-210. DOI:10.1095/biolreprod36.1.203

20. Abe $\mathrm{H}$. The mammalian oviductal epithelium: Regional variations in cytological and functional aspects of the oviductal secretory cells. Histol Histopathol. 1996;11:743-68.

21. Pollard JW, Plante C, King WA, Hansen PJ, Betteridge KJ, Suarez, SS. Fertilizing capacity of bovine sperm may be maintained by binding of oviductal epithelial cells. Biol Reprod. 1991;44:102-107. DOI:10.1095/biolreprod44.1.102

22. Bosch P, Wright JRRW. The oviductal sperm reservoir in domestic mammals. Arch Med Vet. 2005;37(2):95-104. http://dx.doi.org/10.4067/S0301-732X2005000200002.

23. Hebel R, Stromberg MW. Anatomy of laboratory rats. Baltimore; Williams and Wilkins Company; 1976. 76-80 p.

24. Bitto II, Arubi JA, Gumel AA. Reproductive tract morphometry and some haematological characteristics of female rabbits fed pawpaw peel meal-based diets. Afr J Biomed Res. 2006;9:199-204.

25. Natarajan T, Prasad RV, Karade K, Jamuna KV. Histological and histochemical studies on the oviduct of the buffalo (Bubalus bubalis) at different reproductive stages. Indian J Anim Sci. 2003;73:484-487.

26. Ozen A, Ergun E, Kurum A. Histomorphology of the oviduct epithelium in the Angora rabbit. Turkish $\mathrm{J}$ Vet Anim Sci. 2010;34(3):219-226. DOI:10.3906/vet-0710-39

27. Alhasani S, Ven VH, Diedrich K, Hamerich U, Lehmann F, Krebs D. Effect of unilateral salpingectomy on implantation in rabbits. Zucht Hyg. 1984;19(4):145

28. Cheng L, Bostwick DG. Essentials of anatomic pathology. New York: Springer; 2006. $1093 \mathrm{p}$.

29. Al-Saffar FJ, Al-Hasnawy AHA. Histomorphological developmental study of advanced postnatal of the pancreas of local rabbit. J Biol Sci. 2014;14: 387-402. DOI: $10.3923 /$ jbs.2014.387.402

30. Al-Saffar FJ, Al-Haik AG. Histomorphological relationship of paneth cells with stem cells in the small intestine of indigenous rabbit at different postnatal ages. Singapore J Chem Biol. 2016;5(1):11-19. DOI: $10.3923 /$ sjchbio.2016.11.19

31. Al-Saffar FJ, Al-Haik AG. Histochemical study of carbohydrates foundation in the gut of indigenous rabbits at different postnatal ages. Inter J Curr Res. 2016;8(8):37223-37230.

32. Al-Saffar FJ, Al-Haik AG. Histomorphological and Immunohistochemical postnatal developmental changes in the small intestine and colon of the indigenous rabbits (Oryctolagus cuniculus) [PhD dissertation]. Baghdad: Department of Anatomy, Histology and Embryology, College of Veterinary Medicine, Baghdad University; 2017a: 205

33. Al-Saffar FJ, Al-Haik AG. Gross and microscopic developmental study of the local rabbit's spinal cord. J Entomol Zool Stud.2017b; $5(6): 2555-2562$. 